\title{
Changes in Liver Enzymes during Laparoscopic Cholecystectomy under Low and Standard Pressure Pneumoperitoneum
}

\author{
Kumar Sona Brahmaํㅡ, Mituban Gogoi², Nabajyoti Das³, Sorbeswar Bhuyan ${ }^{4}$ \\ ${ }^{1}$ Department of Surgery, Assam Medical College, Dibrugarh, Assam, India. ${ }^{2}$ Department of Surgery, Assam Medical \\ College, Dibrugarh, Assam, India. ${ }^{3}$ Department of Neurosurgery, Assam Medical College, Dibrugarh, Assam, India. \\ ${ }^{4}$ Department of Surgery, Assam Medical College, Dibrugarh, Assam, India.
}

\section{ABSTRACT}

\section{BACKGROUND}

Laparoscopic cholecystectomy (LC) requires the creation of a pneumoperitoneum \{PNP) via insufflations of carbon dioxide, which may result in adverse haemodynamic disturbances leading to visceral organ ischaemia including hepatic dysfunction. The present study was undertaken to compare the changes in hepatic function during LC with standard and during LC with low pressure PNP and also to determine the clinical significances of such disturbances.

\section{METHODS}

A randomised prospective study was conducted among 60 patients from June 2017 to May 2018 for symptomatic gallstones who underwent LC, of which Group A $(n=30)$ were subjected to standard pressure PNP (SPLC= 12 to $14 \mathrm{mmHg}$ ) and Group B $(\mathrm{n}=30)$ to low pressure PNP (LPLC= 7 to $10 \mathrm{mmHg}$ ). Blood samples for liver function test were taken preoperatively and postoperatively. All patients had normal values of preoperative liver function tests.

\section{RESULTS}

Twenty-four hours after the procedure, the mean liver enzymes in both groups were raised, however in SPLC group there was statistically significant elevation of AST $(46.87 \pm 13.90, \mathrm{p}<0.004)$ and ALT $(78.88 \pm 13.86, \mathrm{p}<0.001)$. But the raise was transient and fell off to normal or near normal levels in 7-10 days postoperatively. The changes in ALP and GGT measurements were found to be non-significant.

\section{CONCLUSIONS}

Low pressure pneumoperitoneum has minimal alterations in the liver enzymes thereby reducing the adverse effects on hepatic function, this approach can be considered for patients with compromised liver pathology, particularly in patients undergoing prolonged laparoscopic surgery.

\section{KEY WORDS}

Pneumoperitoneum, Laparoscopic Cholecystectomy, Liver Enzymes, Low Pressure, Standard Pressure, Hepatic Functions
Corresponding Author: Dr. Kumar Sona Brahma, H. No. 22, Near Yuvajyoti Sangha Club, No. 2, Mathgaria, Noonmati, Guwahati-781020, Assam, India. E-mail: drksbrahma@gmail.com

DOI: $10.14260 /$ jemds/2019/791

Financial or Other Competing Interests: None.

How to Cite This Article: Brahma KS, Gogoi M, Das N, et al. Changes in liver enzymes during laparoscopic cholecystectomy under low and standard pressure pneumoperitoneum. J. Evolution Med. Dent. Sci. 2019;8(49):3657-3660, DOI: $10.14260 /$ jemds/2019/791

Submission 03-10-2019, Peer Review 16-11-2019, Acceptance 23-11-2019, Published 09-12-2019. 


\section{BACKGROUND}

Gallstone diseases are the most common problems encountered in surgical practice requiring intervention. With introduction of laparoscopy, laparoscopic cholecystectomy (LC) has become the procedure of choice for removal of the gallbladder offering many advantages when compared to open surgery, including smaller incisions, less pain, and shorter hospitalisation.1,2

However, for laparoscopy, pneumoperitoneum (PNP) is required to create workspace between the abdominal wall and intra-abdominal organs. It is created by insufflating carbon dioxide gas into the peritoneal cavity and then holding it at constant pressure till the end of surgery when it is released at the time of withdrawal of the ports. ${ }^{3}$ Carbon dioxide after absorption is readily excreted via lung. Usually $12 \mathrm{mmHg}$ is sufficient to give a working space in a fully relaxed patient; but when higher pressures are used, they are associated with various adverse complications. The increased intra-abdominal pressure have been associated with impaired functioning of the pulmonary, cardiovascular and intra-abdominal organs, especially the renal and hepatic functions. ${ }^{4}$

The pressure of the created PNP and its duration was shown to influence the degree of hepatic ischaemia. This resulted in elevations of liver enzymes; alanine aminotransferase (ALT), aspartate aminotransferase (AST), alkaline phosphatase (ALP) and gamma glutamyl transferase (GGT). Though, LC is associated with transient elevation of liver enzymes, the disturbances are self-limited and not associated with any morbidity in patients with a normal liver function.5,6,7 An emerging trend has been the use of low pressures for PNP in the range of 8-10 $\mathrm{mmHg}$ instead of the standard pressure PNP in an attempt to lower the impact of PNP on human physiology while providing adequate working space. ${ }^{7}$ It has been postulated that lowering intra-peritoneal pressure levels while performing general laparoscopic surgery would lower surgical complications including lesser post-operative pain, but data remain scarce about significant operative complications.

\section{METHODS}

The objectives of the present study were to evaluate the changes in liver enzymes following low and standard pressure laparoscopic cholecystectomy. And to assess clinical implication of alterations in liver enzymes, if any.

This single centre randomised prospective study was carried out in the Department of General Surgery in a rural tertiary care setup of Assam Medical \& Hospital, in Dibrugarh, India, from June 2017 to May 2018. Patients were randomised into two groups; one group with 30 patients underwent laparoscopic cholecystectomy with standard pressure PNP at 12-14 mmHg (SPLC) while the other group with 30 patients underwent LC with low pressure PNP at 7$10 \mathrm{mmHg}$ (LPLC). The randomisation was based on assigning one individual arbitrarily to one group and then alternating between the two study groups.

Before commencing the study, ethical clearance was obtained from the Institutes' Ethics Committee (Human), and written informed consent was taken after explaining the detailed procedure from each patient in the study groups.

All patients were in age group from 14 to 75 years, with uncomplicated symptomatic gallstone disease. These patients selected for the study had normal values of serum liver enzymes prior to the operations. Any patients with preoperative abnormality in liver enzymes, acute cholecystitis and complications of gallstones, microscopic liver disease, common bile duct pathology, and conversion to open cholecystectomy, haematological disorders, or unwilling for the study were excluded..

In all patients, a standard LC was performed under general anaesthesia with the patients in slight reverse Trendelenburg position and use of 4-trocars technique. The PNP was created by insufflations of $\mathrm{CO} 2$ via open technique. Intra-abdominal pressure was maintained stable at 7-10 $\mathrm{mmHg}$ in group A (Low Pressure) and 12-14 mmHg in group B (Standard Pressure). Monopolar diathermy was used for haemostasis and to detach the gall bladder from its liver bed. After the extraction of gall bladder, surgical drain was placed in subhepatic space. The anaesthetic protocol was same for both groups. The procedure in all the patients was performed by the same team of experienced consultants. Duration of operation was noted. Post-operative symptoms were examined like pain, vomiting, dyspepsia, flatulence and complications like bile leakage, haemorrhage, wound infection etc., and were noted.

The liver enzymes were assessed 24 hrs., after the operation to see the alterations in liver enzymes in both the groups. The normal values were taken according to normal range of Dept. of Biochemistry, Assam Medical College \& Hospital, Dibrugarh. The liver enzymes were repeated again after a week at follow up in those patients who had raised liver enzymes post operatively. Adverse events following the raise of liver enzymes were noted.

\section{Statistical Analysis}

All data were categorised and presented in terms of percentage and mean \pm SD. Statistical significance between two groups were tested by using student (paired and unpaired) t-test and chi-square test, wherever necessary. A p value of less than 0.05 was considered significant.

\section{RESULTS}

The comparative study was carried out from June 2017 to May 2018 in 60 patients undergoing LC. The distribution of age of patients varied from 14 to 75 years in both groups. The mean age in group A (Low Pressure) was 40.77 years with minimum age being 17 years and maximum age of 68 years, whereas in group B (Standard Pressure) the mean age was 39.73 years with minimum age of 14 years and maximum age of 75 years. In both groups the most common age group was 30-39 years. There was no significant difference in mean age in our study. There were 10 male and 20 female in group A as compared to 11 male and 19 female in group B. There was no conversion to open procedure in the study group.

The mean duration of operation was more in LPLC (Group A) than SPLC (Group B) by approximately 4.2 minutes. LPLC took an average of. $60.97 \pm 14.03$ (range 30-92) 
minutes compared to $56.77 \pm 18.49$ (range $30-90$ ) minutes for SPLC, this difference was not statistically significant ( $p>0.05$ ) (table 1).

\begin{tabular}{|c|c|c|c|c|}
\hline \multirow{2}{*}{$\begin{array}{c}\text { In } \\
\text { Minutes) }\end{array}$} & Group A (Low Pressure ) & Group B (Std. Pressure) \\
\hline $1-50$ & $\mathbf{n}$ & $\mathbf{\%}$ & $\mathbf{n}$ & $\mathbf{\%}$ \\
\hline $51-75$ & 9 & 30.00 & 12 & 40.00 \\
\hline $76-100$ & 17 & 56.67 & 13 & 43.33 \\
\hline $101-125$ & 4 & 13.33 & 5 & 16.67 \\
\hline Mean \pm S.D. & 0 & 0.00 & 0 & 0.00 \\
\hline p value ${ }^{\dagger}$ & $60.97 \pm 14.03$ mins. & $56.77 \pm 18.49$ mins. \\
\hline \multicolumn{4}{|c|}{0.325641} \\
\hline Std., Standard; ${ }^{+}$Paired Students ' $t$ ' test \\
\hline
\end{tabular}

In LPLC (Group A), the mean liver enzymes were compared preoperatively and postoperatively and found that the mean was raised postoperatively but the increase was insignificant. It was found that AST were raised in six patients and ALT was raised in two patients postoperatively under low pressure.

In SPLC (Group B), also the mean liver enzymes were raised postoperatively but the elevations of AST and ALT levels were statistically significant. AST was raised in 19 patients and ALT was raised in 20 patients more than its normal values in standard pressure. Though the mean GTP and ALP were raised post operatively but the increase was insignificant (Table 2).

\begin{tabular}{|c|c|c|c|c|c|c|}
\hline \multirow[b]{2}{*}{$\begin{array}{l}\text { (in } \\
U / L)\end{array}$} & \multicolumn{3}{|c|}{ Group A (Low Pressure) } & \multicolumn{3}{|c|}{ Group B (Std. Pressure) } \\
\hline & $\begin{array}{c}\text { Pre- } \\
\text { operative }\end{array}$ & $\begin{array}{c}\text { Post- } \\
\text { operative }\end{array}$ & \begin{tabular}{|c|}
$P$ \\
value
\end{tabular} & $\begin{array}{c}\text { Pre- } \\
\text { operative }\end{array}$ & $\begin{array}{c}\text { Post- } \\
\text { operative }\end{array}$ & p Value Val $^{\dagger}$ \\
\hline AST & $33.07 \pm 4.31^{*}$ & $37.27 \pm 11.25$ & 0.050 & $27.00 \pm 7.94$ & $46.87 \pm 13.90$ & $0.0000(\mathrm{~S})$ \\
\hline ALT & $65.53 \pm 14.03$ & $67.33 \pm 10.84$ & 0.605 & $64.53 \pm 13.83$ & $78.33 \pm 13.86$ & $3(\mathrm{~S})$ \\
\hline ALP & $96.13 \pm 18.53$ & $103.20 \pm 12.30$ & \begin{tabular}{|l|}
0.103 \\
\end{tabular} & $96.50 \pm 15.99$ & $102.83 \pm 13.69$ & \\
\hline GGT & $64.27 \pm 21.78$ & $70.97 \pm 24.74$ & 0.300 & $64.57 \pm 22.33$ & $74.83 \pm 17.26$ & 0.0590 (NS \\
\hline \multicolumn{7}{|c|}{ Table 2. Liver Enzymes Changes (Preoperative \& Postoperative) } \\
\hline \multicolumn{7}{|c|}{$\begin{array}{l}\text { AST, Aspartate Transaminase; ALT, Alanine transaminase; ALP, Alkaline } \\
\text { Phosphatase; GGT, Gamma glutamyl transpeptidase; Std, Standard; S, Significant; N, } \\
\text { Non-significant, *Values are Mean } \pm \text { Standard Deviation; }{ }^{+} \text {paired students ' } t \text { ' test }\end{array}$} \\
\hline
\end{tabular}

On comparing both the groups postoperatively (after 24 hours), the mean liver enzymes were raised in both group but the increase was statistically significant for AST and ALT in SPLC group $(\mathrm{p}<0.05)$. The increase was transient as it fell off to its normal values in 7-10 days during follow-up tests. The raised liver enzymes had no clinical implications on the patients (table 3).

\begin{tabular}{|c|c|c|c|c|c|}
\hline \multirow{2}{*}{$\begin{array}{c}\text { (in } \\
\mathrm{U} / \mathrm{L})\end{array}$} & \multicolumn{2}{|c|}{ Group A (Low Pressure) } & \multicolumn{2}{|c|}{ Group B (Std. Pressure) } & \multirow{2}{*}{$\mathbf{p}^{\dagger}$} \\
\hline & Mean & \pm SD & Mean & \pm SD & \\
\hline AST & 37.27 & 11.25 & 46.87 & 13.90 & $0.004(\mathrm{~S})$ \\
\hline ALT & 67.33 & 10.84 & 78.33 & 13.86 & $0.001(\mathrm{~S})$ \\
\hline ALP & 103.20 & 12.30 & 103.10 & 14.07 & $0.976(\mathrm{NS})$ \\
\hline GGT & 70.97 & 24.74 & 74.83 & 17.26 & $0.485(\mathrm{NS})$ \\
\hline \multicolumn{6}{|c|}{ Table 3. Liver Enzymes Changes (Postoperative) } \\
\hline \multicolumn{6}{|c|}{$\begin{array}{l}\text { AST, Aspartate Transaminase; ALT, Alanine transaminase; ALP, Alkaline } \\
\text { Phosphatase; GGT, Gamma glutamyl transpeptidase; Std, Standard; S, Significant; N, } \\
\text { Non-significant. *Values are Mean } \pm \text { Standard Deviation; }{ }^{\dagger} \text { paired students ' } t \text { ' test }\end{array}$} \\
\hline
\end{tabular}

\section{DISCUSSION}

Liver function tests (LFT) are used as an indicator for evaluation of biliary obstruction in the preoperative period where there are elevated levels of alkaline phosphatase, and also in postoperative period for assessment of biliary injury or ligation where the liver functions are immediately deranged. Many studies have shown changes in LFTs in patients undergoing laparoscopic cholecystectomy. Carboxyperitoneum may be the prime reason for these liver enzymes changes in LC, as these alterations are not observed in open cholecystectomy (OC) as carbon dioxide is not used in OC. During laparoscopic surgery, there is an elevation and depression of intra-abdominal pressure (IAP) in a short time, this sudden alteration of IAP could cause undulation of portal blood flow. This undulation in blood flow and re-irrigation of organs may give rise to ischaemia and re-irrigation damage of tissues and organs, especially the Kupffer and endothelial cells of hepatic sinusoids. This can cause free radical generation. ${ }^{8}$ The role of reperfusion related mechanisms after laparoscopy and the production of free radicals are however smaller than the role of total surgical injury during open cholecystectomy.

\begin{tabular}{|c|c|c|c|}
\hline Study & Liver Enzymes & Preoperative (IU/L) & Postoperative (IU/L) \\
\hline \multirow{2}{*}{\begin{tabular}{|c|} 
Sakorafas \\
et al $(2005)^{9}$
\end{tabular}} & AST & $22.3 \pm 12.1$ & $87.1 \pm 24.2^{*}$ \\
\hline & ALT & $21.6 \pm 13.4$ & $82.8 \pm 19.1$ \\
\hline \multirow{2}{*}{\begin{tabular}{|c|} 
Guven et al \\
$(2007)^{10}$
\end{tabular}} & AST & $22.76 \pm 6.44$ & $61.72 \pm 28.13$ \\
\hline & ALT & $21.55 \pm 8.92$ & $60.30 \pm 32.17$ \\
\hline \multirow{2}{*}{$\begin{array}{l}\text { Omari et al } \\
(2007)^{11}\end{array}$} & AST & $21.15 \pm 8.23$ & $37.39 \pm 15.88$ \\
\hline & ALT & $19.6 \pm 10.46$ & $35.93 \pm 20.47$ \\
\hline \multirow{2}{*}{$\begin{array}{l}\text { Singal et al } \\
(2015)^{12}\end{array}$} & AST & $27.0 \pm 8.1$ & $72.9 \pm 13.1$ \\
\hline & ALT & $26.0 \pm 8.9$ & $72.4 \pm 12.9$ \\
\hline \multirow{2}{*}{$\begin{array}{l}\text { Arora B } \\
(2016)^{13}\end{array}$} & AST & $28.2 \pm 6.4$ & $36.6 \pm 4.6$ \\
\hline & ALT & $29.1 \pm 8.6$ & $37.9 \pm 3.4$ \\
\hline \multirow{2}{*}{$\begin{array}{c}\text { Naikoo et al } \\
(2018)^{14}\end{array}$} & AST & $32.2 \pm 7.2$ & $74.6 \pm 11.4$ \\
\hline & ALT & $31.6 \pm 6.9$ & $73.4 \pm 11.1$ \\
\hline \multirow{2}{*}{ Our Study } & AST & $27.00 \pm 7.94$ & $46.87 \pm 13.90$ \\
\hline & ALT & $64.83 \pm 13.83$ & $78.33 \pm 13.86$ \\
\hline \multicolumn{4}{|c|}{$\begin{array}{l}\text { Table 4. Comparison of Changes in Mean Values of AST and } \\
\text { ALT in Various Studies }\end{array}$} \\
\hline \multicolumn{4}{|c|}{$\begin{array}{l}\text { AST, Aspartate Transaminase; ALT, Alanine transaminase. *Values are Mean } \pm \\
\text { Standard Deviation }\end{array}$} \\
\hline
\end{tabular}

It is seen that in the present study most of the liver enzymes has increased postoperatively in SPLC but it is insignificant except for AST \& ALT. The rise in liver enzymes has no clinical implication on the patients and the rise was transient, as it returned to normal values after a week when the patients were reassessed for liver enzymes during follow up. The results of our study was consistent with studies shown in Table 4 like Sakorafas et al (2005), ${ }^{9}$ Guven et al (2007),10 Omari et al (2007), ${ }^{11}$ Singhal et al (2015),12 Arora B et $\mathrm{al}(2016)^{13}$ and Naikoo et al (2018).14 They have also stated that after $24 \mathrm{hrs}$. of LC there is significant increase in AST \& ALT levels, but the raise had no significant clinical implication in the patients. The raise of liver enzymes was due to the creation of PNP which reduces the portal vein blood flow and can cause alterations in liver function by sublethal ischaemia of hepatic cells leading to release of enzymes into circulation. ${ }^{13}$

In the present study, liver enzymes were raised in 8 patients out of 30 patients in LPLC group. AST were raised in six patients postoperatively more than its normal value and ALT were raised in two patients. The raises in liver enzymes were clinically insignificant. Similar results were found in other studies by Hasukic et al (2005)7, Ambole et al (2017) ${ }^{15}$ and Giraudo et al (2001). ${ }^{16}$ Studies by Guven et al (2007) ${ }^{10}$ and Singhal et al (2015) ${ }^{12}$ showed changes to ALP and GGT similar to the results our study, where there was no significant alterations in the levels of serum ALP and GGT postoperatively. These changes were transient and they returned to near normal values within a few days postoperatively. 
Studies conducted by Guven et al (2007),10 Al-Luwaizi KR et al (2013) ${ }^{17}$ and Singhal et al $(2015)^{12}$ found that these changes did not occur in patients undergoing open surgeries, where patients were divided into two groups, one group underwent LC and the other open cholecystectomy. There were no significant changes in the levels of serum liver enzymes of patients undergoing open surgery. Also Tan et $\mathrm{al}(2003)^{18}$ found statistically significant increased levels of hepatic transaminases during the first 48 hours after operation in patients undergoing LC and laparoscopic colonic resection compared to patients undergoing open procedures.

\section{CONCLUSIONS}

With the advancement of laparoscopy, laparoscopic cholecystectomy has become the gold standard for treatment of gallstone diseases. To mitigate the effects of carboxyperitoneum which is an essential requirement for laparoscopy, low pressure pneumoperitoneum can be an alternative. Low pressure PNP has minimal alterations in the liver enzymes thereby reducing the adverse effects on hepatic function. This approach can be considered for patients with compromised liver pathology, particularly in patients undergoing prolonged laparoscopic surgery for better postoperative recovery.

\section{REFERENCES}

[1] Cuschieri A. Laparoscopic cholecystectomy. J R Coll Surg Edinb 1999;44(3):187-92.

[2] Sood J, Kumra VP. Anaesthesia for laparoscopic surgery. Indian J Surg 2003;65:232-40.

[3] Chok KS, Yuen WK, Lau H, et al. Prospective randomized trial on low pressure versus standard pressure pneumoperitoneum in outpatient laparoscopic cholecystectomy. Surg Laparosc Endosc Percutan Tech 2006;16(6):383-6.

[4] Gutt CN, Oniu T, Mehrabi A, et al. Circulatory and respiratory complications of carbon dioxide insufflation. Dig Surg 2004;21(2):95-105.

[5] Hasukic S, Kosuta D, Muminhodzic K. Comparison of postoperative hepatic function between laparoscopic and open cholecystectomy. Med Princ Pract
2005;14(3):147-50.

[6] Morino M, Giraudo G, Festa V, et al. Alterations in hepatic function during laparoscopic surgery. An experimental clinical study. Surg Endosc 1998;12(7):968-72.

[7] Hasukic S. Postoperative changes in liver function tests: randomized comparison of low- and high-pressure laparoscopic cholecystectomy. Surg Endosc 2005;19(11):1451-5.

[8] Sare M, Yilmaz I, Hamamci D, et al. The effect of carbon dioxide pneumoperitoneum on free radicals. Surg Endosc 2000;14(7):649-52.

[9] Sakorafas GH, Anagnostopoulos GK, Stafyla V, et al. Elevation of serum liver enzymes after laparoscopic cholecystectomy. N Z Med J 2005;118(1210):U1317.

[10] Guven HE, Oral S. Liver enzyme alterations after laparoscopic cholecystectomy. J Gastrointestin Liver Dis 2007;16(4):391-4.

[11] Omari A, Bani-Hani KE. Effect of carbon dioxide pneumoperitoneum on liver function following laparoscopic cholecystectomy. J Laparoendosc Adv Surg Tech 2007;17(4):419-24.

[12] Singal R, Singal RP, Sandhu K, et al. Evaluation and comparison of postoperative levels of serum bilirubin, serum transaminases and alkaline phosphatase in laparoscopic cholecystectomy versus open cholecystectomy. J Gastrointest Oncol 2015;6(5):479-86.

[13] Arora B. Liver enzymes Alterations after laparoscopic cholecystectomy. J Medical Science Clin Res 2016;4(3):9765-8.

[14] Naikoo ZA, Hakeem V, Akhter G, et al. Effect of laparoscopic cholecystectomy on liver function: a single institution study at a district level hospital. Glob J Res Anal 2018;7(2):647-9.

[15] Ambole AS, Gayithri Kulkarni G, Biradar JM, et al. Assessment of LFTs in patients undergoing cholecystectomy. J Adv Med Dent Sci Res 2017;05 (11):18.

[16] Giraudo G, Contul BR, Caccetta M, et al. Gasless laparoscopy could avoid alterations in hepatic function. Surg Endosc 2001;15(7):741-6.

[17] Al-Luwaizia KR, Hamad SO. Changes of liver enzymes and serum bilirubin after laparoscopic cholecystectomy. Ann Coll Med Mosul 2013;39(2):113-7.

[18] Tan M, Xu FF, Peng JS, et al. Changes in the level of serum liver enzymes after laparoscopic surgery. World J Gstroenterol 2003;9(2):364-7. 